\title{
Eksperimen Material pada Masker Non-Medis dengan Memperhatikan Faktor Komunikasi Non-Verbal dan Estetika
}

\author{
Pingki Indrianti ${ }^{1 *}$, Oki Kurniawan ${ }^{2}$ \\ ${ }^{1}$ Program Studi Desain Mode, Politeknik Negeri Media Kreatif, Jakarta, Indonesia \\ ${ }^{2}$ Program Studi Desain Produk, Universitas Trilogi, Jakarta, Indonesia
}

\begin{abstract}
Since the COVID-19 pandemic, the Indonesian government has implemented the $5 \mathrm{M}$ health protocol (washing hands, maintaining distance, wearing masks, avoiding crowds, maintaining body immunity). Along with the appeal for the use of masks for the general public, non-medical covers made of cloth (cloth masks) with various and unique designs have emerged, specifically to support a lifestyle. From the results of observations through several sources, there is another need for cloth masks, namely for nonverbal communication on facial expressions (facial kinesics). When using a mask, facial expressions are often invisible, especially in mouth movements (lips). This nonverbal communication will undoubtedly be needed for both the deaf and speechimpaired people and society in general. This study aims to determine the characteristics of non-medical cloth mask materials that can support the convenience of facial kinesic non-verbal communication. The material is also considered in terms of visual aesthetics so that the mask can still keep the appearance of everyday attire. This study uses a qualitative approach with experimental methods on several non-medical masks with various material variations. The results showed that masks with a combination of transparent materials such as synthetic organza dove fabric (polyamide) and PVC plastic were sufficient to help nonverbal communication on facial expressions while still having droplet and aerosol protection. This research needs to be improved by utilizing filtration technology to make the mask more comfortable.
\end{abstract}

\section{Keywords}

clear mask, mask material, non-medical mask, nonverbal communication, facial kinesics. 


\title{
Eksperimen Material pada Masker Non-Medis dengan Memperhatikan Faktor Komunikasi Non-Verbal dan Estetika
}

\author{
Pingki Indrianti \& Oki Kurniawan
}

\section{PENDAHULUAN}

Indonesia saat ini memasuki babak baru dalam penanganan COVID-19, New Normal atau kebiasaan hidup baru merupakan kebijakan yang diambil oleh pemerintah Indonesia untuk mengurangi penularan COVID-19 sekaligus salah satunya menjaga stabilitas ekonomi negara. Sejumlah skema dan rencana telah disiapkan pemerintah dalam rangka membuka kembali aktivitas sosial ekonomi Indonesia di tengah pasien positif korona yang masih meningkat hingga saat ini. Melalui situs resmi Gugus Tugas Percepatan Penanganan virus korona Indonesia (covid19.go.id), Presiden Jokowi menyebutkan bahwa dalam rangka pembukaan kembali sejumlah sektor menuju fase masyarakat yang produktif dan aman dari COVID-19 harus melalui sejumlah tahapan yang ketat dan hati-hati. Presiden mengeluarkan lima arahan (5M), yaitu menggunakan masker, menjaga jarak, mencuci tangan, menghindari kerumunan atau keramaian, serta menjaga imunitas tubuh. Himbauan menggunakan masker juga dijelaskan dalam buku pedoman pencegahan COVID-19 Kementerian Kesehatan [1]. Menurut penelitian Leung, dkk [2] penggunaan masker dapat menjadi salah satu kontrol untuk menghentikan penyebaran virus (COVID-19) dimana titik air (droplet) sebagai sumber penularan dapat berubah menjadi partikel kecil di udara yang bersifat aerosol sehingga beresiko untuk terhirup, sehingga penting bagi masyarakat untuk selalu menggunakan masker.

Saat ini muncul beragam masker nonmedis berbahan kain (cloth mask) dengan desain yang beragam dan unik. Masker kain ini banyak didesain untuk mendukung gaya hidup masyarakat sehingga tetap dapat tampil modis. Kondisi new normal menjadikan masker sebagai bagian dari gaya hidup (lifestyle) berpakaian masyarakat sehari-hari, bahkan sebagai 'kebudayaan baru' [3]. Pada masa new normal ini, masyarakat tetap harus menggunakan masker namun seringkali merasa kesulitan dalam berkomunikasi. Sulitnya berkomunikasi dikarenakan kejelasan volume suara berkurang karena terhalang oleh kain masker, serta gerak bibir (ekspresi wajah) yang tidak terbaca. Faktor komunikasi ini juga dijelaskan dalam Buku Panduan Interim WHO (2020) tentang penggunaan masker dalam konteks COVID-19 [4].

Saat sejumlah industri kecil-menengah di Indonesia telah mengembangkan masker difabel tuna rungu dan tuna wicara untuk membantu komunikasi non-verbal khususnya membaca ekspresi wajah gerak bibir [5], namun demikian desain masker yang dihasilkan belum lazim digunakan oleh masyarakat umum. Masker transparan (clear mask) yang beredar menggunakan kombinasi material kain tekstil dengan material plastik bening PVC yang diletakan di bagian tengah masker atau di bagian mulut sehingga menyerupai bentuk jendela. Masker model ini juga memiliki permasalahan lain seperti pantulan cahaya dipermukaan plastik yang menghambat penampakan gerak bibir, serta munculnya embun dan uap nafas yang dihasilkan saat berbicara sehingga kurang nyaman digunakan[6], [7]. Selain masker difabel, sejumlah masker transparan juga mulai beredar disejumlah situs belanja (toko online) di Indonesia umumnya menggunakan material plastik. Berdasarkan mayoritas komentar pengguna produk, masker ini disebutkan terlihat berembun.

Pada sisi yang lain muncul trend dimana sejumlah masyarakat lebih memilih untuk mengganti masker dengan alat pelindung diri berupa face shield [8]. Hal ini dikarenakan face shield lebih mudah untuk dibersihkan dibandingkan masker serta membantu proses komunikasi dalam hal ekspresi wajah, seperti saat berkomunikasi dengan orang yang memiliki gangguan pendengaran [9]. Penggunaan face shield ini juga marak di Indonesia khususnya diacara hiburan televisi maupun pertunjukan yang mana penggunaan masker bagi para talent yang sedang berlakon akan cukup sulit untuk dilakukan [10]. Penggunaan masker saat pertunjukan tentunya juga menyulitkan penampil untuk melihat ekspresi wajah penonton [11]. Namun demikian face shield secara keseluruhan tidak efektif untuk menahan penyebaran droplet dibandingkan dengan masker (medis maupun nonmedis). Walaupun face shield 
menawarkan visual yang lebih baik dan lebih mudah dibersihkan, menggunakan masker tetap dianggap lebih baik dan dapat membantu mencegah penyebaran virus COVID-19 [8].

Penelitian ini bertujuan untuk menentukan karakteristik material masker kain nonmedis yang dapat mendukung komunikasi nonverbal khususnya kinesik fasial (ekspresi wajah), serta dari segi estetika visual (tampilan masker). Teori yang digunakan pada penelitian ini adalah teori komunikasi nonverbal dan teori komponen desain mode. Luaran yang dihasilkan adalah purwarupa eksperimen masker dengan beberapa kombinasi material.

\section{Komunikasi Non-Verbal}

Menurut West dan Turner [12] komunikasi merupakan suatu proses sosial dimana sejumlah individu menggunakan sejumlah simbol untuk menciptakan dan menginterpretasikan makna dalam lingkungan mereka. Komunikasi juga merupakan satu proses memberi dan menerima makna antar dua individu [13] yaitu komunikator dan komunikan. Dengan kata lain komunikasi merupakan proses penyampaian pesan antar sesama manusia yang terdiri dari unsur pengirim pesan (komunikator), pesan, media, penerima pesan (komunikan), serta timbal balik (respon) terhadap pesan tersebut.

Komunikasi verbal adalah komunikasi dengan menggunakan kata-kata, baik secara lisan maupun tulisan. Terdapat dua unsur penting dalam komunikasi verbail yaitu "Kata" dan "Bahasa". Komunikasi verbal terdiri dari dua jenis, yaitu komunikasi verbal dengan berbicara dan menulis, serta komunikasi verbal dengan mendengarkan dan membaca [14]. Sedangkan komuniksi nonverbal merupakan komunikasi selain kata-kata yang terucap dan tertulis. Pesan komunikasi nonverbal memiliki kode nonverbal, yaitu sejumlah perilaku yang digunakan untuk menyampaikan makna atau dikenal dengan "bahasa isyarat" atau "bahasa diam" (silent language). Makna kode nonverbal ini memiliki arti yang berbeda pada setiap budaya [15]. Dalam kehidupan sehari-hari antar komunikasi verbal dan nonverbal saling berkaitan atau melengkapi satu sama lain.

Komunikasi nonverbal terdiri dari beberapa jenis (Kurniati, ibid) yaitu, sentuhan (haptics), komunikasi objek, kronemik (chronemics) atau komunikasi berdasarkan pemahaman terhadap penggunaan waktu (disesuaikan dengan budaya setempat), gerakan tubuh (kinesics), dan proxemics (bahasa ruang, yaitu jarak yang gunakan ketika berkomunikasi dengan orang lain).

Pesan kinesik adalah pesan nonverbal yang ditunjukan seseorang melalui isyarat tubuh atau gerakan badan [16]. Pesan kinesik memiliki tiga komponen utama, (a) Pesan Fasial yaitu pesan yang menggunakan air muka atau ekspresi wajah; (b) Pesan Gestural yaitu pesan yang menunjukkan gerakan sebagian anggota badan seperti gerakan tangan untuk mengkomunikasi berbagai makna; (c) Pesan Postural yaitu pesan yang berkenaan dengan keseluruhan anggota badan, postur tubuh dapat mempengaruhi citra diri yang dimiliki seseorang.

Berdasarkan penelitian tentang ekspresi wajah $[15,17]$ terdapat tiga ciri yang dapat digunakan untuk menentukan ekspresi wajah seseorang yaitu gerakan alis dan kelopak mata, pipi, beberapa orang melalui hidung, dan gerakan mulut (bibir).

Tabel 1. Ekspresi wajah atau pesan kinesik fasial

\begin{tabular}{|c|c|c|c|c|c|}
\hline No & $\begin{array}{l}\text { Ekspresi } \\
\text { Wajah }\end{array}$ & Mata dan Alis & Pipi & Hidung & Mulut \\
\hline 1 & Bahagia & $\begin{array}{l}\text { Bagian bawah } \\
\text { kelopak } \\
\text { mata agak } \\
\text { vterangkat, } \\
\text { terlihat ada } \\
\text { kerutan dan } \\
\text { mata menyipit. }\end{array}$ & $\begin{array}{l}\text { Memerah dan } \\
\text { mem esar }\end{array}$ & - & $\begin{array}{l}\text { Bibir dan } \\
\text { mulut melebar, } \\
\text { terkadang gigi } \\
\text { terlihat }\end{array}$ \\
\hline 2 & Sedih & $\begin{array}{l}\text { Ujung dalam } \\
\text { alis terangkat, } \\
\text { mata berlinang } \\
\text { air mata. }\end{array}$ & - & - & $\begin{array}{l}\text { Sudut mulut } \\
\text { tertarik ke } \\
\text { bawah dan } \\
\text { bibir gemetar. }\end{array}$ \\
\hline 3 & Marah & $\begin{array}{l}\text { Alis ditarik ke } \\
\text { dalam, mata } \\
\text { menyipit. }\end{array}$ & - & $\begin{array}{l}\text { Beberapa orang } \\
\text { mengembangkan } \\
\text { hidung. }\end{array}$ & $\begin{array}{l}\text { Bibir tertutup } \\
\text { rapat. }\end{array}$ \\
\hline
\end{tabular}




\section{Komponen Desain Mode}

Pada sebuah produk mode (fesyen) keindahan dan keserasian menjadi tujuan utama, daya tarik menjadi hal penting yang harus dipertimbangkan baik dalam merancang, memilih, dan menggunakan suatu produk busana. Keindahan atau estetika memiliki kaitan erat dengan unsur-unsur seperti garis, bentuk, warna, dan lain sebagainya. Pada fashion terdapat empat unsur $[18,19]$ yang disebut sebagai The Components of fashion yang terdiri dari siluet atau bentuk (silhouette atau shape), tekstur (texture), detail (detail), dan warna (color).

Siluet atau bentuk atau struktur, yaitu area yang menggambarkan bentuk keseluruhan dan struktur yang nampak dari produk mode khususnya sebuah busana. Siluet (Stone, ibid) terdiri dari Siluet bellshaped, wedge, rectangle, tubular, trapezium, dan lainnya). Sedangkan menurut Dineva [20] dapat dibedakan menjadi non-volumetric (tidak memiliki volume) dan volumetric (memiliki volume).

Detail yaitu bagian kecil suatu busana yang dapat menciptakan kesan dan perhatian lebih pada produk mode. Contoh detail adalah bentuk kerah, bentuk pergelangan tangan atau manset (cuffs), bentuk lengan dan bahu/pundak, trimming (kancing, zipper), ruffle (kain kerut atau bergelombang), pleats (lipatan-lipatan kecil), potongan dibagian kantong, dan lain sebagainya.

Warna, merupakan elemen pertama yang terlihat. Warna dapat mempengaruhi psikologi dan perasaan seseorang. Warna secara teori dasar terdiri dari warna primer, warna sekunder, tersier dan kombinasinya (chromatic, analogous, split complementer, dan lain sebagainya). Warna juga merujuk pada gelap-terang atau intensitas cahaya pada warna.

Tekstur merujuk pada kualitas permukaan yang mempengaruhi indera perabaan manusia. Pada sebuah desain, tekstur dapat merujuk pada penggunaan kain (material) termasuk jenis serat tekstil, teknik pembuatan (tenun, rajut), maupun penyelesaian yang digunakan (motif cetak tekstil, bordir, dan lainnya).

\section{HASIL DISKUSI}

Penelitian ini menggunakan desain penelitian kualitatif melalui pendekatan eksperimen, dengan ragam material masker sebagai sampel penelitian. Studi eksperimen bertujuan untuk meneliti pengaruh perlakuan tertentu yang dihasilkan suatu kelompok, terhadap kelompok lain (yang memiliki perlakuan berbeda) dalam kondisi terkendalikan [21]. Sedangkan menurut Alwasilah [22] istilah eksperimental merujuk pada kontrol suatu data yang diakses oleh peneliti; dalam hal ini masker kain nonmedis diberikan perlakuan dan pengendalian (kontrol) melalui berbagai karakteristik material, kemudian membandingkan karakter yang dihasilkan serta melakukan analisis terhadap kemampuan untuk mendukung komunikasi nonverbal kinesik fasial (ekrpresi wajah) serta estetika masker.

Pada penelitian kualitatif ini penulis berperan sebagai instrumen data yang menggunakan dua sumber data yaitu data tertulis (studi literartur) serta benda (objek) yang diamati untuk melihat pengaruh perbedaan perlakuan, dalam hal ini karakteristik material masker. Penelitian kualitatif bersifat alamiah, sehingga hasilnya tidak dapat dipastikan sebelum penelitian selesai. Penilaian terhadap hasil eksperimen, dilakukan melalui diskusi panel dengan mewawancarai sejumlah narasumber yang merupakan pakar atau ahli di bidangnya.

Eksperimen pada penelitian ini terdiri dari tiga tahapan yaitu, (a) Penentuan Material, (b) Proses eksperimen (pembuatan purwarupa masker dengan penerapan berbagai jenis material), (c) Evaluasi hasil eksperimen masker.

\section{Penentuan Material}

Material masker yang digunakan pada eksperimen, terdiri dari dua lapisan yaitu kombinasi antar material plastik (kedap air) dan kain (menyerap air), hal ini dilakukan untuk menyesuaikan panduan dan pertimbangan praktis masker nonmedis [4] tentang lapisan dalam masker memiliki karakter menyerap air (hidrofilik) sehingga dapat langsung menyerap droplet dan dikombinasikan bahan sintetis yang tidak mudah menyerap cairan (hidrofobik) untuk lapisan luar.

Kombinasi material juga mempertimbangkan segi estetika visual sehingga masker dapat terlihat menarik namun tetap memperhatikan kemampuan komunikasi nonverbal kinesik fasial (ekspresi wajah).

Jenis material yang digunakan pada eksperimen adalah plastik EVA dengan tekstur dove, plastik mika bening (PVC), kain silk rayon, dan organza sintetis (poliamida/nilon). Berikut adalah definisi dan 
penjelasan masing-masing material.

EVA (Ethylene-Vinyl Acetate) merupakan perpaduan (copolymer) dari ethilen dan vinil asetat, dengan komposisi berat vinil asetat berkisar antara 10-40\%, sisanya ethilen (60-90\%). Beberapa karakter material EVA adalah tahan air (kedap air), tahan terhadap korosi (air laut, minyak, asam, alkali dan bahan kimia lain), antibakteri, tidak beracun, tidak berbau, limbah tidak menghasilkan polusi, daya tarik (resilience) tinggi. Produk yang dihasilkan dapat berupa plastik (untuk jas hujan atau tas), foamtape, karet, dan lainnya. Sedangkan PVC (Polivinil klorida) adalah salah satu material penghasil polimer sintetis (plastik) yang paling banyak digunakan di dunia. Karakteristik utama PVC adalah daya tahan api yang tinggi (sehingga sering digunakan sebagai material pada produk tahan api). PVC juga tahan air, isolasi, memiliki struktur yang hampir mirip dengan kayu (dapat digergaji, dipaku, dibor), sifat kimia stabil, ketahanan kimia yang baik, PVC berbusa rendah memiliki efek polusi lingkungan yang rendah serta dapat didaur ulang. Produk yang dihasilkan adalah pipa air, kabel, alat-alat medis, tas plastik, jas hujan, plastik penutup meja, dan lain sebagainya [23].

Gambar 1 Jas hujan plastik EVA Dove (kiri, tengah) dan tas plastik PVC (kanan)

(Sumber: id.aliexpress. com/item/32852821449)
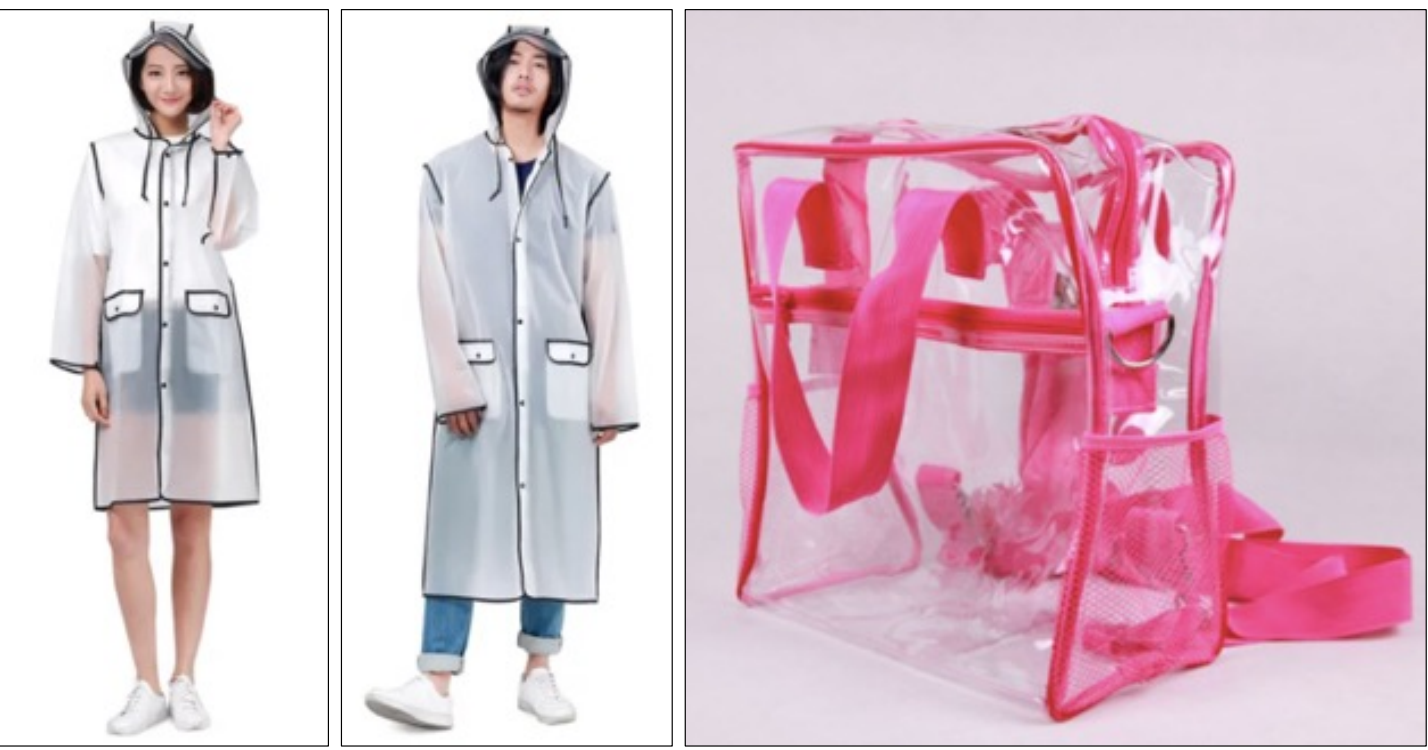

Silk-Rayon (Sutera-rayon) merupakan perpaduan antara serat alam sutera dan regenerated fiber (rayon). Rayon merupakan serat yang berasal dari hasil daur ulang limbah serat alam (kapas) maupun pulp kayu dengan ukuran yang sangat kecil. Rayon dapat menyerupai karakteristik serat kapas seperti memiliki konduktivitas yang tinggi (nyaman digunakan), sekaligus memiliki tekstur halus sedikit berkilau yang menyerupai sutera dengan cara memproduksi serat panjang (filament) pada rayon. Silkrayon digunakan sebagai material eksperimen masker karena kemampuannya dalam menyerap panas tubuh (nyaman digunakan) serta dapat menyerap air dengan cukup baik), memiliki karakter tekstur yang cukup menerawang, dapat membantu proses komunikasi; dan harga material Silk-rayon yang terjangkau dapat membantu menekan biaya produksi dibandingkan menggunakan serat $100 \%$ sutera.

Kain organza adalah kain yang berasal dari negara Perancis. Awalnya kain ini bernama Organdi yang terbuat dari $100 \%$ serat sutera atau $100 \%$ serat kapas yang disisir hingga halus dan menerawang. Harga yang cukup mahal, saat ini kebanyakan kain organza yang terdapat di pasaran terbuat dari serat sintetis seperti nilon (poliamida) dan poliester. Kain organza dikenal dengan "kain kaca" karena karakternya yang kaku dan memiliki daya kilau yang tinggi. Terdapat beberapa jenis kain organza diantaranya Kain Organza Deluxe Silk dengan tekstur lembut, organza standar (sintetis) dengan tekstur sedikit lebih kaku dari jenis kain organza silk, organza kasar (sintetis) bertekstur sangat kaku.

Penulis memilih kain organza dengan jenis standar (sintetis) karena karakter kain menerawang (transparan), berkilau, warna yang bervariasi dan menarik, serta tekstur yang cukup halus sehingga dapat terlihat menarik sekaligus nyaman digunakan.

\section{Proses Eksperimen (Pembuatan Purwarupa Masker)}

Pembuatan Eksperimen masker diawali dengan mencari referensi tentang bentuk atau model masker yang paling nyaman digunakan serta sesuai dengan tujuan penelitian. Bentuk yang yang digunakan pada eksperimen adalah masker duckbill atau masker berbentuk paruh bebek. Bentuk masker ini memiliki lebih banyak ruang udara antara masker dengan mulut dan hidung, sehingga lebih 
nyaman bernafas. Berdasarkan pengamatan penulis, masker ini banyak dijual di pasaran dan digunakan oleh masyarakat. Beberapa merk dagang yang mengeluarkan masker jenis ini diantaranya SENSI, 3M, Bellini, EVO Plusmed, dan lain sebagainya.
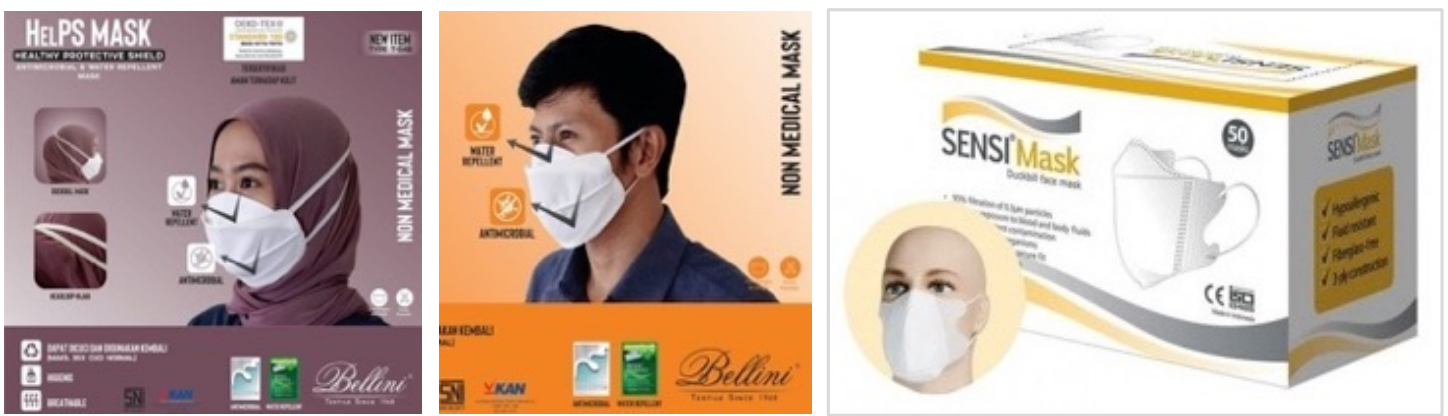

Gambar 1 Model masker duckbill merk SENSI dan Bellini (Sumber: www.bukalapak.com)

Berdasarkan bentuk masker tersebut, penulis memilih bentuk masker duckbill SENSI dan 3M untuk bagian muka (depan), dengan mengkombinasikan bentuk hidung atas pada masker Bellini. Potongan depan masker SENSI dan 3M dengan arah vertikal dianggap sesuai untuk membantu visual ekspresi wajah.

\section{Eksperimen Masker 1}
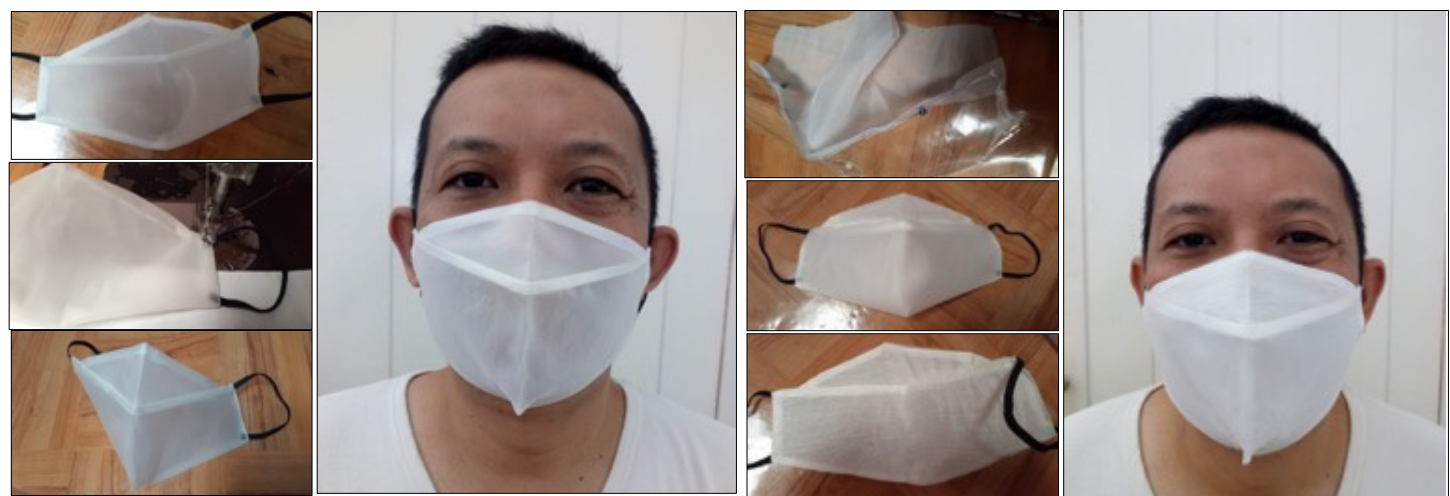

Gambar 2 Hasil Eksperimen Makser 1 dengan material plastik EVA dove dan silk-rayon (kiri); Hasil Eksperimen Makser 2 dengan material plastik EVA dove dan organza dove (kanan)

Pada eksperimen 1, masker duckbill dibuat dengan menggunakan material plastik EVA berwarna putih dan silk-rayon berwarna putih gading. Hasil eksperimen memperlihatkan estetika visual yang sangat menarik, perpaduan tekstur transparan dan dove (lembut tidak berkilau) pada plastik EVA di bagian luar masker dengan silk-rayon di bagian dalam, menghasilkan bentuk dan tekstur masker yang menarik. Image atau citra yang dihasilkan edgy dan modern. Perpaduan material ini juga memberikan struktur dan tekstur yang nyaman saat digunakan, karena karakter silk-rayon yang lembut dan plastik EVA yang lentur. Karakter rayon yang menyerap air juga mengurangi uap air dan embun saat bernafas.

Material pada eksperimen masker 1 masih cukup menghalangi visual gerak mulut. Efek tekstur dove memberikan kejelasan permukaan (clarity) yang kurang baik, sehingga siluet gerak mulut (bibir) tidak terlihat.

\section{Eksperimen Masker 2}

Masker eksperimen 2 menggunakan material plastik EVA dove, dengan kombinasi kain organza regular (standar) yang memiliki tekstur sedikit dove, transparan, dan lembut dikulit. Eksperimen ini memperlihatkan hasil yang tidak terlalu berbeda dengan eksperimen masker 1 . Hal ini menunjukan bahwa material plastik EVA, walau memiliki tampilan visual yang menarik dan lentur, namun tidak dapat memberikan visualisasi dan kejelasan gerak mulut (bibir) yang baik. Material organza dove yang lebih menerawang dibandingkan silk-rayon membantu sedikit kejelasan visual gerak mulut (bibir), tapi tidak maksimal dan masih terlihat sangat samar.

Apabila digunakan, masker ini nyaman digunakan, hal ini dikarenakan plastik EVA yang lentur serta organza dove yang sedikit kaku namun tetap fleksibel dan lembut di kulit. Namun demikian karakteristik material organza dove sintetis tetap tidak membantu karakteristik plastik EVA menjadi 
lebih menerawang. Selain itu organza sintetis tidak terlalu menyerap air, sehingga muncul sedikit embun dan uap air saat bernafas, walaupun uap air dan embun dapat ditahan dengan baik oleh plastik EVA yang kedap air, namun hal ini dapat mengganggu penampakan gerakan mulut (bibir).

\section{Eksperimen Masker 3}

Eksperimen ini menggunakan kombinasi material plastik PVC bening (tidak berwarna) dibagian luar dan organza putih dove dibagian dalam. Apabila dibandingkan dengan eksperimen sebelumnya pada material plastik EVA, kejelasan atau kejernihan (clarity) tekstur masker lebih terlihat pada eksperimen dengan plastik PVC ini. Hal ini dimungkinkan karena tekstur transparan yang lebih jernih pada plastik PVC dibandingkan plastik EVA dove. Penulis memilih untuk menggunakan material organza dove, karena berdasarkan eksperimen sebelum nya material kain silk-rayon kurang berhasil dalam menampakan gerakan bibir. Tingkat kejelasan pada silk-rayon kurang baik dibandingkan dengan kain organza dove.

Kombinasi material plastik PVC dan kain organza dove pada eksperimen 3 menghasilkan tekstur masker yang lebih jernih sehingga mampu memperlihatkan gerakan bibir walaupun tidak sebening kaca. Beberapa gerakan bibir seperti senyuman simpul, senyuman lebar, dan beberapa gerakan mulut terlihat samar namun jelas pada masker ini.
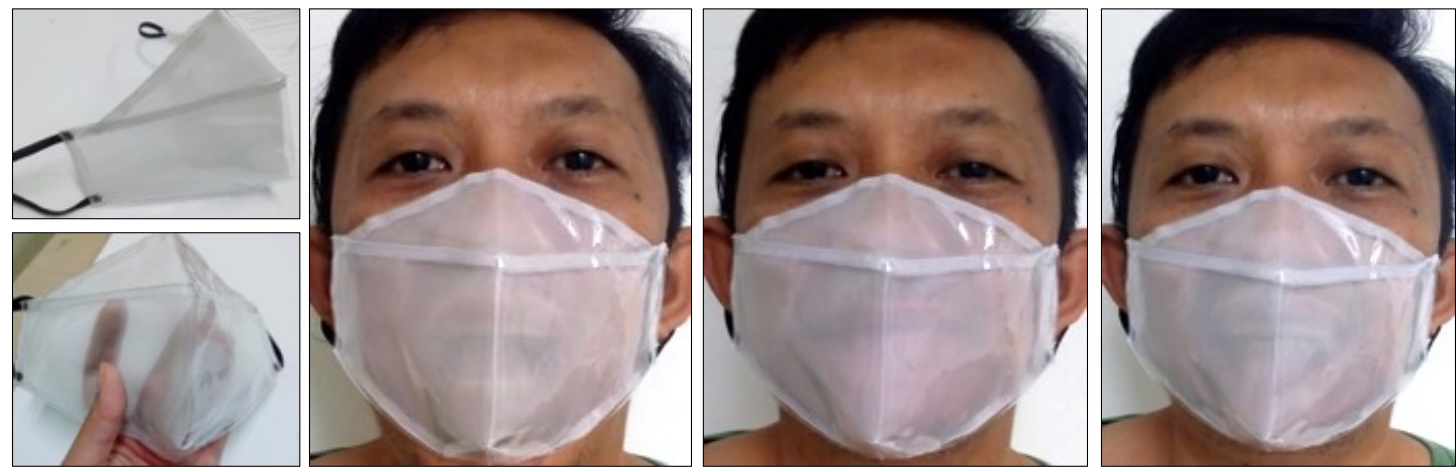

Gambar 3 Hasil Eksperimen Masker 3 dengan material plastik PVC dan organza dove

Berdasarkan tampilan visual, masker eksperimen 3 juga terlihat menarik, walaupun masih lebih unggul tampilan eksperimen 1 dan 2 yang menggunakan plastik EVA putih dove. Saat digunakan, masker terasa nyaman karena karakteristik organza dove yang lembut dan cukup fleksibel.

Namun demikian, kekurangan masker ini adalah karakter kain organza sintetis yang tidak terlalu menyerap air, sehingga muncul sedikit embun dan uap air saat bernafas. Walaupun uap air dan embun dapat ditahan dengan baik oleh plastik PVC yang kedap air, namun hal ini sedikit mengganggu penampakan gerakan mulut (bibir), khususnya jika masker digunakan dalam jangka waktu yang lama.

Penulis melakukan eksperimen dengan menggunakan masker eksperimen 3 selama satu jam, hasil nya adalah masker yang digunakan menjadi berembun, walaupun penampakan gerak mulut masih terlihat, namun embun mengurangi kejelasan (clarity) pada permukaan masker.

\section{Eksperimen Masker 4}
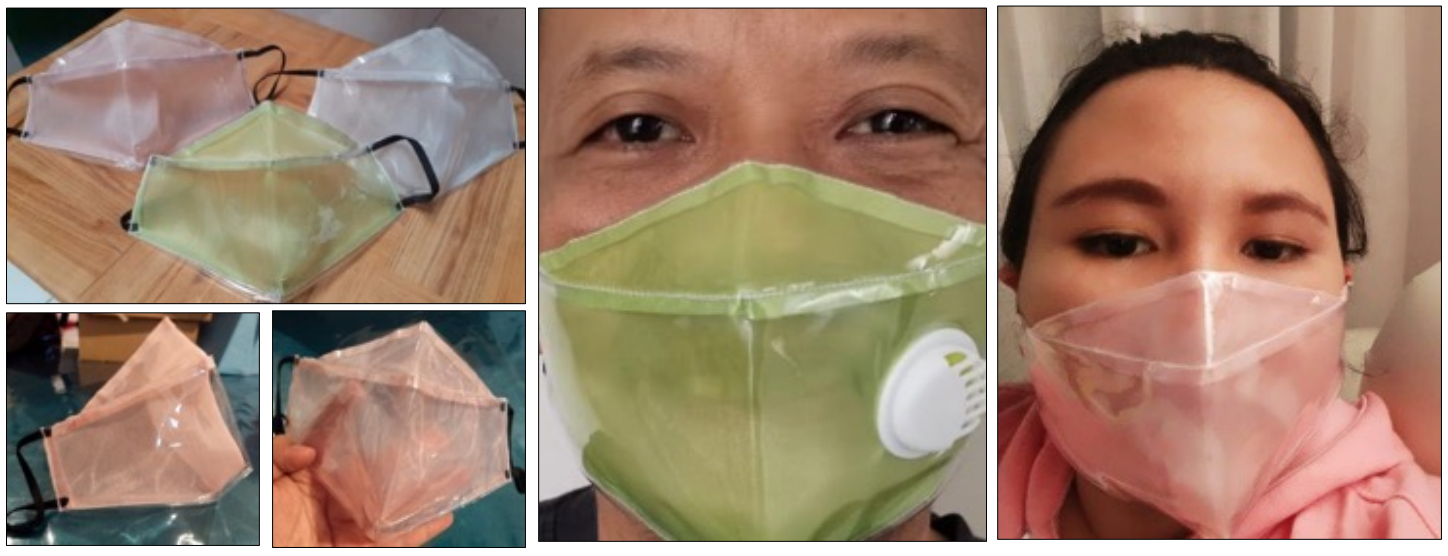

Gambar 5 Hasil Eksperimen Makser 4 dengan material plastik PVC dan organza dove berwarna 
Masker eksperimen 4 menyerupai masker eksperimen 3 yaitu menggunakan material plastik PVC dan kain organza dove, namun demikian pada eksperimen ini penulis menggunakan organza berwarna merah muda (pink) terang dan hijau terang (hijau 'stabilo'). Penulis bermaksud melihat perbedaan visual tekstur antara masker putih dengan masker berwarna baik dari segi penampakan gerakan mulut dan tampilan desain masker.

Berdasarkan pengamatan penulis, gerakan bibir pada masker eksperimen 4 masih terlihat jelas dengan menggunakan material berwarna (bukan putih), selain itu tampilan tekstur masker menjadi terlihat lebih menarik dan bervariasi. Kesan yang didapat adalah masker yang modern dan trendi. Namun demikian penggunaan warna ini perlu diperhatikan tingkat kecerahan warnanya, sebab jika menggunakan warna gelap akan mengganggu penampakan gerakan bibir.

Pada eksperimen 4, penulis juga menambahkan filter (katup) masker, hal ini dikarenakan masker berwarna, saat terkena embun nafas, menjadi kurang terlihat jika dibandingkan masker berwarna putih. Sehingga diharapkan filter dapat mengurangi uap dan embun nafas. Namun demikian setelah pemakaian 5 menit, filter Nampak tidak bekerja dengan baik, embun masker terlihat tidak berkurang. Walaupun demikian, tampilan image masker dengan menggunakan filter ini menjadi semakin menarik karena masker tidak berkesan terlalu polos dan sederhana.

\section{Evaluasi Hasil Eksperimen Masker}

Evaluasi hasil eksperimen dilakukan dengan cara diskusi panel bersama tiga orang narasumber yang merupakan pakar atau ahli. Narasumber atau panelis yang dipilih adalah dosen. Purwarupa masker yang digunakan pada diskusi panelis adalah masker hasil eksperimen 3 dan 4.

Materi penilaian pada diskusi ini dibagi menjadi dua yaitu faktor komunikasi nonverbal khususnya kinesik fasial (ekspresi wajah) dan estetika (desain). Panelis materi komunikasi merupakan seorang dosen sekaligus pakar dengan kompetensi bidang ilmu komunikasi, sedangkan panelis pada materi estetika adalah dosen dengan kompetensi bidang desain mode \& tekstil, serta desain produk.

Pertanyaan pada diskusi panel materi komunikasi terdiri dari enam pertanyaan yang mencakup empat bahasan (a) Karakteristik material masker nonmedis pada eksperimen, dapat mendukung komunikasi nonverbal kinesik fasial; (b) Persepsi panelis dalam melihat perbedaan antar gerakan mulut (bibir); (c) Warna material yang mendukung kejelasan visual ekspresi; (d) Gangguan (embun nafas) pada kejelasan visual ekspresi. Sedangkan pada diskusi panel materi estetika terdiri dari lima pertanyaan yang mencakup tiga bahasan, (a) Penerapan material masker dilihat dari segi prinsip desain (keseimbangan dan harmoni); (b) Penerapan warna masker terhadap image (citra) yang dihasilkan; (c) Kenyamanan material saat digunakan.

Tabel 2. Evaluasi panelis untuk faktor komunikasi nonverbal kinesik fasial (ekspresi wajah)

\begin{tabular}{|c|c|c|}
\hline $\begin{array}{c}\text { Hasil Eksperi- } \\
\text { men }\end{array}$ & Pertanyaan diskusi & Pendapat panelis \\
\hline & $\begin{array}{l}\text { Menurut anda, apakah karakteristik } \\
\text { material masker nonmedis pada eks- } \\
\text { perimen ini dapat mendukung komu- } \\
\text { nikasi nonverbal kinesik fasial melalui } \\
\text { Gerakan mulut (bibir)? Apakah Sangat } \\
\text { jelas/jelas/cukup jelas }\end{array}$ & $\begin{array}{l}\text { Karakteristik material masker non medis } \\
\text { sampel ini dapat mendukung komunikasi } \\
\text { nonverbal gerakan mulut dengan jelas. Sep- } \\
\text { erti komunikan dapat melihat dengan jelas } \\
\text { senyum dari komunikator. }\end{array}$ \\
\hline & $\begin{array}{l}\text { Menurut anda, apakah saat menggu- } \\
\text { nakan masker tersebut, terdapat per- } \\
\text { bedaan antar gerakan mulut yang satu } \\
\text { dengan gerakan mulut yang lain? }\end{array}$ & $\begin{array}{l}\text { Pada saat menggunakan masker terlihat } \\
\text { perbedaan gerakan mulut yang satu dengan } \\
\text { lainnya. Perubahan dari tidak tersenyum ke } \\
\text { senyum jelas terlihat. }\end{array}$ \\
\hline & $\begin{array}{l}\text { Gerakan mulut (bibir) seperti apa yang } \\
\text { menurut anda paling terlihat saat } \\
\text { menggunakan sampel masker dengan } \\
\text { material tersebut? (bibir terbuka den- } \\
\text { gan gigi terlihat/ bibir tertutup rapat/ } \\
\text { senyum simpul/senyum biasa/ Senyum }\end{array}$ & $\begin{array}{l}\text { Urutan yang paling jelas terlihat adalah: } \\
\text { 1. Bibir terbuka dengan gigi terlihat. } \\
\text { 2. Senyum lebar } \\
\text { 3. Senyum biasa } \\
\text { 4. Bibir tertutup rapat. }\end{array}$ \\
\hline
\end{tabular}




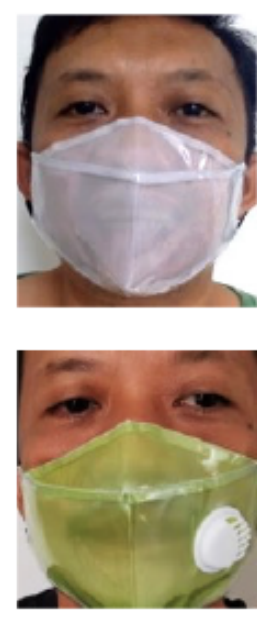

?ika diberikan urutan, mana gerakan mulut yang paling terlihat sampa tidak terlihat

Menurut anda apakah warna putih Warna putih dengan bahan transparan bisa pada material masker membantu terli- membantu untuk melihat gerakan mulut. hatnya gerakan mulut?

Menurut anda apakah jika masker Warna lain selain putih sangat memunmenggunakan material berwarna hi- gkinkan. Namun, komunikan akan sedikit jau terang atau pink terang, gerak bibir teralihkan (perhatiannya) pada saat awal. tetap dapat terlihat? Bisa menjadi hambatan dalam memahami pesan yang disampaikan komunikator. Seperti warna pink.

Menurut anda, apakah embun nafas Embun nafas bisa menjadi hambatan juga. pada masker dapat mengurangi tingkat Idealnya adalah masker harus bisa dipastikejelasan gerakan mulut (bibir) kan tidak berembun dan pengguna masker pun dapat bernafas dengan nyaman. Mulut adalah bagian yang cukup penting dalam memahami ekspresi seseorang.

Tabel 3. Evaluasi panelis terhadap desain masker (kombinasi material dan warna masker)

\begin{tabular}{|c|c|c|c|}
\hline $\begin{array}{l}\text { Hasil } \\
\text { men }\end{array}$ & Eksperi- & Pertanyaan diskusi & Pendapat panelis \\
\hline & & $\begin{array}{l}\text { Menurut anda bagaimana pen- } \\
\text { erapan kombinasi material } \\
\text { masker (tekstur dan warna) dili- } \\
\text { hat dari segi prinsip desain (kes- } \\
\text { eimbangan dan kesatuan)? }\end{array}$ & $\begin{array}{l}\text { Secara keseluruhan perpaduan antara } \\
\text { tekstur material plastik bening dan kain } \\
\text { dove, memperlihatkan adanya keseim- } \\
\text { bangan dan kesatuan. Pepaduan war- } \\
\text { na juga terlihat seimbang. }\end{array}$ \\
\hline & & $\begin{array}{l}\text { Apakah material masker mau- } \\
\text { pun penerapan bentuk nya su- } \\
\text { dah terlihat menarik dari segi } \\
\text { estetika? }\end{array}$ & $\begin{array}{l}\text { Secara keseluruhan bentuk, masker } \\
\text { terlihat menarik, namun material plastik } \\
\text { terlalu kaku, sehingga terlihat kurang } \\
\text { pas di bagian hidung. Bisa dicoba (un- } \\
\text { tuk potongan masker di bagian hidung } \\
\text { atas) cukup menggunakan kain organ- } \\
\text { za saja. }\end{array}$ \\
\hline & & & $\begin{array}{l}\text { Penggunaan filter menambah kesan } \\
\text { visual masker menjadi lebih menarik. } \\
\text { Masker terlihat lebih "serius" (terlihat } \\
\text { sesuai standar bukan seperti masker } \\
\text { mainan) saat menggunakan filter ini. }\end{array}$ \\
\hline & & $\begin{array}{l}\text { Menurut anda, bagaimana } \\
\text { image (citra) yang dihasilkan } \\
\text { masker dengan menggunakan } \\
\text { perpaduan material ini baik dari } \\
\text { segi warna dan tekstur? }\end{array}$ & $\begin{array}{l}\text { Masker terlihat 'kekinian' dengan pad- } \\
\text { uan tekstur bening plastik dan kain } \\
\text { organza transparan. Image dari warna } \\
\text { masker pink/hijau (bukan putih) juga } \\
\text { terlihat 'anak muda' sekali (youthful dan } \\
\text { energic). }\end{array}$ \\
\hline & & $\begin{array}{l}\text { Menurut anda apakah masker } \\
\text { nyaman digunakan ? (dari segi } \\
\text { material, jahitan, dan warna) }\end{array}$ & $\begin{array}{l}\text { Sedikit kurang nyaman karena cukup } \\
\text { kaku. Dapat dicoba membuat masker } \\
\text { dalam berbagai ukuran (M, L, XL) se- } \\
\text { hingga dapat menyesuaikan berbagai } \\
\text { ukuran bidang wajah. Atau dapat juga } \\
\text { menggunakan kain saja (tanpa lapisan }\end{array}$ \\
\hline & & & $\begin{array}{l}\text { plastik) dipotongan hidung atas, kemu- } \\
\text { ngkinan bisa lebih tidak terasa kaku. } \\
\text { Kain organza juga belum terlalu maksi- } \\
\text { mal menyerap embun (walaupun tera- }\end{array}$ \\
\hline
\end{tabular}




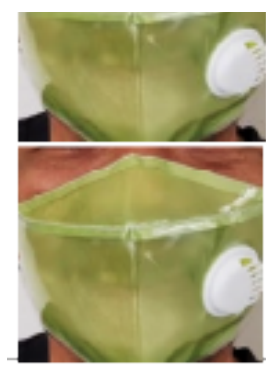

sa lebih baik dibandingkan jika hanya menggunakan plastik saja).

Seharusnya filter dapat menambah nilai fungsi masker dengan lebih baik, namun fitter yang digunakan ini tidak memberikan efek apapun. Memilih jenis dan kualitas fiter untuk digunakan pada masker menjadi faktor yang sangat penting.

\section{KESIMPULAN}

Pada era new normal seperti sekarang ini, pengunaan alat pelindung diri seperti masker kain merupakan salah satu hal penting yang harus diterapkan masyarakat dalam aktivitas sehari-hari khususnya dalam pencegahan penyebaran virus COVID-19. Penggunaan masker juga merupakan bagian dari arahan pemerintah melalui 5M (mencuci tangan, menjaga jarak, menggunakan masker, menghindari kerumunan, dan menjaga imunitas tubuh). Saat ini masker kain (cloth mask) telah memiliki ragam tampilan yang bervariasi dan menarik, hal ini untuk mendukung gaya hidup masyarakat, sehingga dapat menjalankan protokol kesehatan namun tetap dapat tampil modis dalam beraktivitas sehari-hari. Namun demikian material masker yang ada saat ini, umumnya masih membatasi proses komunikasi khususnya dalam komunikasi kinesik fasial atau ekspresi wajah. Gerakan mulut (bibir) pada ekspresi wajah seperti senyum biasa atau tertawa lebar, tidak terlihat saat menggunakan masker. Selain itu, walau saat ini telah dikembangkan masker tuna rungu yang dapat melihat gerakan mulut (bibir), desain masker yang ditawarkan masih kurang sesuai dengan masker yang biasa digunakan masyarakat pada umumnya, selain itu material plastik yang langsung menyentuh mulut seringkali membuat tidak nyaman pengguna termasuk munculnya embun nafas.

Berdasarkan hasil eksperimen dan diskusi dengan panelis, kombinasi material plastik EVA dove dengan silk-rayon maupun organza dove berwarna putih terlihat tidak dapat mendukung komunikasi dengan ekspresi wajah. Kejelasan (clarity) permukaan masker sangat kurang sehingga gerakan mulut (bibir) tidak terlihat saat menggunakan masker.

Berbeda dengan hasil eksperimen dengan kombinasi material plastik bening PVC dan organza dove berwarna putih, menghasilkan kejelasan dan tekstur yang lebih baik. Gerakan bibir terlihat jelas walau sedikit samar. Karakter organza dove yang lembut membuat masker nyaman digunakan di kulit, namun demikian karakter organza dove yang kurang menyerap air, menyebabkan saat bernafas, masker terdapat embun walaupun penampakan gerak bibir masih cukup terlihat hal ini tentu saja akan mengganggu proses komunikasi.

Masker dengan material PVC bening dengan kain organza berwarna terang seperti hijau 'stabilo' dan pink cerah, memberikan tampilan masker yang lebih bervariasi dan menarik dibandingkan hanya menggunakan warna putih. Kesan atau Image yang dihasilkan dari masker ini adalah energic (dynamic) dan youthful. Penggunaan filter juga memberikan visual yang lebih menarik, namun secara fungsi tidak memberikan efek apapun.

Penelitian ini diharapkan dapat mendukung salah satu protokol kesehatan pemerintah yaitu menggunakan masker di era kebiasaan baru (new normal). Eksperimen ini perlu disempurnakan melalui berbagai alternatif material serta proses dan teknik produksi yang lebih maju (canggih) begitu juga dengan pemanfaatan teknologi filtrasi, sehingga masker transparan tidak hanya mampu mendukung komunikasi nonverbal dan terihat estetik, namun juga memiliki nilai kenyamanan serta proteksi terhadap penyebaran virus (droplet dan aerosol).

\section{UCAPAN TERIMAKASIH}

Penulis mengucapkan rasa terima kasih yang besar atas kerjasama, kritik, dan saran dari para panelis; kepada Ibu Diah Amelia, S.Hum., M.Si (Dosen bidang ilmu komunikasi Program Studi Penerbitan Politenik Negeri Media Kreatif Jakarta), Ibu Rina Watye, M.Ds (Dosen bidang ilmu desain mode \& tekstil Program Studi Desain Mode Politeknik Negeri Media Kreatif Jakarta) serta Bapak Dedy Rachmad Setiawardhana, S.T., M.Ds (Dosen bidang ilmu desain produk Program Studi Desain Produk Universitas Trilogi). 


\section{DAFTAR PUSTAKA}

[1]. Aziza, L. Aqmarina, A. \& Ihsan, M. (eds) Buku Pedoman Pencegahan Dan Pengendalian Coronavirus Disesase (Covid-19). Jakarta: Kementerian Kesehatan Republik Indonesia, 2020.

[2]. Leung, N.H.L. Chu, D.K.W. Shiu, E.Y.C. et al. Author Correction: Respiratory virus shedding in exhaled breath and efficacy of face masks. Nature Medicine, 2020; 26: 981-981.

[3]. Oelze, S. Protective masks: A new culture in Germany. DW.com, https://www.dw.com/en/ protective-masks-a-new-culture-in-germany/a-53294964 (2020, accessed 5 January 2020).

[4]. WHO Advice on the use of masks in the context of COVID-19 in Term Guidance, World Health Organization (WHO). WHO, 2020.

[5]. P., C.N. \& Kustiani, R. Ada Masker Kain Transparan Supaya Difabel Bisa Baca Gerak Bibir. Tempo.com, https://difabel.tempo.co/read/1328843/ada-masker-kain-transparan-supayadifabel-bisa-baca-gerak-bibir (2020).

[6]. Syamsi, S. \& Arief, A. Masker Transparan Perlu Inovasi Baru. Solider.id, https://www.solider.id/ baca/5915-masker-transparan-perlu-inovasi-baru (2020).

[7]. J., C. Elite Readers. www.elitereaders.com, https://www.elitereaders.com/show-your-smilewhile-staying-covid-protected-with-the-worlds-first-fda-approved-transparent-mask/ (2020).

[8]. Verma, S. Dhanak, M. \& Frankenfield, J. Visualizing droplet dispersal for face shields and masks with exhalation valves. Physics of Fluids, 2020; 32: 091701.

[9]. Perencevich, E.N. Diekema, D.J. \& Edmond, M.B. Moving Personal Protective Equipment Into the Community. JAMA, 2020; 323: 2252.

[10]. Vebrynda, R. Film di Tengah Pandemi Covid-19. In: Junaedi F (ed) Dinamika Komunikasi di Masa Pandemi Covid-19. Yogyakarta: Buku Litera, 2020, pp. 195-201.

[11]. Djunaedy, M.F. Geliat Dunia Stand Up Comedy di Masa Pandemi. In: Junaedi F (ed) Dinamika Komunikasi di Masa Pandemi Covid-19. Yogyakarta: Buku Litera, 2020, pp. 202-212.

[12]. West, R. \& Turner, L.H. Pengantar Teori Komunikasi: Analisis dan Aplikasi Buku. Jakarta: Salemba Empat, 2008.

[13]. Aththar, M.A.A.- The Magic of Communication: Kiat Ampuh menjadi Pribadi yang Menarik dan Berpengaruh. Jakarta: Zaman, 2016.

[14]. Kurniati, D.P.Y. Modul Komunikasi Verbal dan Non Verbal (Komunikasi Kesehatan). Denpasar, https://simdos.unud.ac.id/uploads/file_pendidikan_dir/ a3a4fc3bf4ad19b0079f4a31c593398b.pdf (2016).

[15]. Putri, I. Komunikasi Non Verbal (Makna Kinesik) Pesulap Dalam Pertunjukan Sulap Klasik. Syi'ar, 2018; 18: 56-73.

[16]. Rakhmat, J. Psikologi komunikasi. Bandung: Remaja Rosdakarya, 2007.

[17]. Vijaya, K. Body Language : Memahami Bahasa Yang Disampaikan Tubuh. Jakarta: TUGU, 2013.

[18]. Seivewright, S. Basics Fashion Design 01: Research and Design. Lausanne, Switzerland: Bloomsbury Publishing PLC, 2007.

[19]. Stone, E. \& Farnan, S.A. The Dynamic of Fashion. 5th Editio. New York: Bloomsbury, 2018.

[20]. Dineva, P. \& Ilieva, J. Fashion design of silhouettes with the use of 3D elements. Applied Researches in Technics, Technologies and Education, 2016; 4: 80-90.

[21]. Sugiyono Metode Penelitian Kuantitatif, Kualitatif, dan R\&D. Bandung: Alfabeta, 2011.

[22]. Alwasilah, C. Pokoknya Kualitatif : Dasar-Dasar Merancang Dan Melakukan Penelitian Kualitatif. Jakarta: Pustaka Jaya, 2011.

[23]. Plastik, H. Perbedaan antara PVC dan EVA. id.pvctransparent.com, http://id.pvctransparent. com/info/the-difference-between-pvc-and-eva-28540207.html (2018, accessed 5 January 2021). 